\title{
Vaccine Innovation and Adoption: Polio Vaccines in the UK, the Netherlands and West Germany, 1955-1965
}

\author{
ULRIKE LINDNER and STUART S BLUME*
}

\begin{abstract}
Introduction: Vaccine Innovation
"An effective AIDS vaccine could be found as early as 2012, saving 6 million lives if the world is willing to put $£ 10$ bn a year into a new programme, the chancellor, Gordon Brown, said in a speech last night in Tanzania". ${ }^{1}$ Faith in biomedical science; the conviction that new vaccines will be translated into lives saved; belief in the necessity of globally concerted action: the British minister's statement reflects views of vaccine innovation that are widely held today. New and improved vaccines seem our best hope of coping with the scourge of AIDS, of arming ourselves against the unknown threats of emergent diseases and potential bioterrorism, and of tackling the resurgence of old diseases arising once more in Europe. Global coordination, pooling our resources, seems self-evidently necessary, given the international nature of a modern epidemic. Much current discussion of vaccine development and use thus has a global character. That is to say, it is conducted under the banner of global slogans ${ }^{2}$ or it seeks to establish globally integrated approaches to vaccine research and development (R\&D). ${ }^{3}$ Over the past two decades the development and rapid introduction of new vaccines have come to dominate the vaccine agenda worldwide. ${ }^{4}$ Social scientists and health policy analysts have been set to work, examining barriers to the implementation of international priorities at the national level. Why, for example, are national responses to the availability of new vaccines often so lethargic? A recent study of the adoption of Hemophilus influenza $b$ (Hib) conjugate vaccine is a good example. ${ }^{5}$ It shows policy makers in four countries rationally weighing the burden to public health of the diseases against which the vaccine offers protection (bacterial meningitis and
\end{abstract}

(C) Ulrike Lindner and Stuart S Blume 2006

* Ulrike Lindner, PhD, Clare Hall, Herschel Road, Cambridge CB3 9AL, and Prof. Dr Stuart S Blume, Amsterdam School for Social Science Research, University of Amsterdam, o.z. Achterburgwal 185, 1012 DK Amsterdam,The Netherlands.

We would like to thank the Wellcome Trust for support of part of the research on which this paper is based, Dr H Cohen and Dr R J F Burgmeijer for their help and advice. We would also like to thank the Medical History referees for their helpful comments on an earlier draft of this paper.

${ }^{1} \mathrm{P}$ Wintour, 'Aids vaccine possible by 2012 , Brown tells Africa', Guardian, 13 Jan. 2005, p. 10.

\footnotetext{
${ }^{2}$ A Hardon and S Blume, 'Shifts in global immunisation goals (1984-2004): unfinished agendas and mixed results', Soc. Sci. Med., 2005, 60: 345-56.

${ }^{3}$ For example, R D Klausner, A S Fauci, L Corey, et al., 'The need for a global HIV vaccine enterprise', Science, 2003, 300: 2036-9.

${ }^{4} \mathrm{~W}$ Muraskin, The politics of international health: the Children's Vaccine Initiative and the struggle to develop vaccines for the third world, Albany, SUNY Press, 1998.

${ }^{5} \mathrm{~J}$ D Wenger, J DiFabio, J M Landaverde, O S Levine and T Gaafar, 'Introduction of Hib conjugate vaccines in the non-industrialized world: experience in four "newly adopting" countries', Vaccine, 1999, 18: 736-42.
} 


\section{Ulrike Lindner and Stuart S Blume}

pneumonia), against the high cost of the vaccine. Health policy analysts tend to explain the decision to introduce a new vaccine, or to replace an existing vaccine by a new alternative, in terms of the epidemiology and seriousness of the disease, and of scientific consensus regarding the efficacy and potential risks of the vaccine and (perhaps) their costs. The studies of vaccine diffusion and adoption that they conduct have little or nothing to say about political disagreements, or the influence of commercial interests, national traditions, international relations, or global agendas. Where any attention is paid to vaccine history, it is generally in the attempt to illustrate factors (such as resistance to vaccination) that might cause deviations from the rational deployment of vaccines. ${ }^{6}$

Do - and more importantly can — scientific and epidemiological data determine vaccine policy in the way assumed by most contemporary policy analysis? The very different idea that, far from being determinant, scientific, epidemiological and economic data are subject to construction and reconstruction by political actors, has been central to recent historical analysis. When a hepatitis B vaccine was licensed for use in the UK in 1982, DHSS guidelines issued soon afterwards drew attention to its limited availability, high cost, and the low rate of occurrence of the disease. ${ }^{7}$ Jennifer Stanton has analysed the debate to which these restrictive recommendations then led, and which continued intermittently into the 1990s. The debate focused on fears regarding the safety of the vaccine (produced from carrier blood plasma) and on the groups to which vaccine should be offered. The pharmaceutical company marketing the vaccine in the UK participated actively in the debate. So did segments of the medical profession, in ways that often reflected differing perceptions of their being at risk. "Although vaccine policy was set by the Department of Health," she concludes, ". . . it was implemented by regional health authorities. As with other historical examples, the delegation of final responsibility for decisions about who should receive the vaccine, from the centre to the peripheries, acted as a very effective brake on the wider uptake of the vaccine. At every level, advice was sought ... from medical experts ... but (again with historical parallels) this medical opinion was often divided and unable to push very strongly in one direction". ${ }^{8}$ Subsequently, changes in the law affecting the liability of health authorities as employers, the availability of a new recombinant vaccine, and advocacy by international health bodies, all played their part in a gradual evolution in thinking and in policy.

Comparative historical analysis of national responses to the development of a new vaccine can serve to highlight influences or assumptions that might otherwise be invisible, because unarticulated. It can also help us understand better how scientific and epidemiological data are differently construed. Linda Bryder's analysis of responses to the development of BCG (Bacillus Calmette-Guérin) vaccine, in the early 1920s, is exemplary in this respect. ${ }^{9}$ Whilst Scandinavian countries rapidly introduced BCG vaccination in the

\footnotetext{
${ }^{6}$ A M Stern and H Markel, 'The history of vaccines and immunization: familiar patterns, new challenges', Health Affairs, 2005, 24: 611-21.

${ }^{7}$ J Stanton, 'What shapes vaccine policy? The case of hepatitis B in the UK', Soc. Hist. Med., 1994, 7: $427-46$.

${ }^{8}$ Ibid., p. 444.

${ }^{9}$ L Bryder, " "We shall not find salvation in inoculation": BCG vaccination in Scandinavia,
}

Britain and the USA, 1921-1960', Soc. Sci. Med. 1999, 49: 1157-67; see also C Bonah, " "As safe as milk or sugar water": perceptions of the risks and benefits of the BDG vaccine in the 1920s and 1930s in France and Germany', in T Schlich and U Tröhler (eds), The risks of medical innovation: risk perception and assessment in historical context, Abingdon and New York, Routledge, 2006, pp. 71-92. 


\section{Polio Vaccine Innovation and Adoption}

attempt to combat tuberculosis, Britain introduced it only in 1950, whilst in the USA the vaccine was scarcely used. "All three countries claimed their policies were rooted in scientific research; if so, why did the interpretation of the same research, together with some locally conducted research, yield such different results?" asks Bryder. ${ }^{10}$ In Denmark, Norway and Sweden, local studies, as well as the convictions of influential physicians, led to growing use of BCG through the 1920s, 1930s and 1940s. Despite the fact that no randomized controlled trials were conducted in Scandinavia, the vaccine came to be accepted as a major protective weapon against tuberculosis. By contrast, British scientists remained sceptical. Evidence from Scandinavia was seen as non-conclusive, given that no randomized trials had been conducted. Scientific doubts and objections were accompanied by, and have to be seen in the context of, other convictions that played an important role. Most important, argues Bryder, was the conviction that Britain already had an effective system of tuberculosis control with which vaccination would only interfere. Specialized sanatoria were central to this system, as was an "ideology of self-responsibility and selfcontrol". The objective should not be to provide a false sense of security through vaccination, but to encourage healthy and responsible life-styles. It was only after the Second World War, with the coming of the National Health Service and its new commitment to greater equality in health care provisions, and an administrative (and manpower) crisis in the residential institutions, that BCG came to be widely accepted. In the USA too, the safety and efficacy of the vaccine were initially doubted, and there was a similar fear that mass vaccination would interfere with existing approaches to tuberculosis control. By the 1950s, despite (or because of) endorsement of BCG in Britain, debate in the USA had become all the fiercer. Central to professional opposition, argues Bryder, was the commitment of American specialists to existing, curative, approaches. Tuberculosis specialists were unwilling to be convinced by any evidence for the effectiveness of mass vaccination and were not, as in Britain, challenged either by institutional crisis or a major shift in public health ideology. Not so much the scientific evidence, always open to differing interpretations, as differences in social welfare traditions and systems seem to explain these major national differences.

Taken together, these two careful historical accounts of vaccine introduction point in a direction very different from that of today's health policy analyses. Both Stanton and Bryder emphasize the non-determinant character of scientific and medical data: data that are almost inevitably subject to alternative interpretations. They draw our attention, first, to the structure of health care systems. Decentralization of responsibility to the British health care regions acted as a brake on the introduction of the hepatitis B vaccine. They draw our attention, second, to the importance of existing welfare traditions and professional commitments. These suggestions form the starting point for the analysis offered here.

It is important to note that each of these interpretations of vaccine innovation and diffusion has been theorized and used empirically by other authors, most relevantly in studies of medical innovation. For example, in their study of forms and consequences of state intervention in health care (which compares Britain, France, Sweden and the United States over the period 1890-1970) Rogers Hollingsworth and his co-authors devote a chapter to a comparison of the adoption and diffusion of medical technologies in these

\footnotetext{
${ }^{10}$ Bryder, op. cit., note 9 above, p. 1157.
} 


\section{Ulrike Lindner and Stuart S Blume}

countries. They seek to understand how the structure of a delivery system, and its degree of state control and finance, influences the adoption and spread of medical innovations. ${ }^{11}$ Looking specifically at smallpox vaccine in the nineteenth century, they conclude that the "degree of state intervention ... precisely matches the progression in the diffusion of smallpox vaccine ... its impact outweighs sharp differences in social development, professionalization, and specialization". ${ }^{12}$ This conclusion can be seen as a generalization of Stanton's point regarding the significance of decentralization.

The notion of path dependency tries to capture the influence of prior commitments and traditions of the kind emphasized by Bryder. Looking at a number of examples of innovations in health care in the United States, the historian David Rothman has stressed the influence of national characteristics and institutions. ${ }^{13}$ Rothman uses the term path dependency to characterize the iteration between institutions and choices. Quoting Robert Putnam, he writes, "What comes first ... conditions what comes later. Individuals may 'choose' their institutions, but they do not choose them under circumstances of their own making, and their choices in turn influence the rules within which their successors choose". ${ }^{14}$ Focusing on successions of technologies more generally, a number of economic historians and historians of technology have also tried to theorize the ways in which experience in using a technology shapes attempts at its improvement, whilst excluding alternative technological approaches. The concept of "lock in", applied most famously by Paul David to explain persistence of the QWERTY typewriter keyboard, ${ }^{15}$ is closely related to that of path dependency and has proved very fruitful in the study of technological change.

Our focus in this paper is on the introduction of vaccines against poliomyelitis in the Federal Republic of Germany (West Germany), Great Britain and the Netherlands. Public health authorities in the three countries responded very differently to the emergence of both the Salk polio vaccine (IPV) in the mid-1950s and the Sabin polio vaccine (OPV) a few years later. In trying to understand how and why this was so, ${ }^{16}$ we will focus in particular on the relevance (and the adequacy) of the themes we have drawn from the studies by Stanton and by Bryder. We will also make use of theoretical approaches, such as those noted above, used by sociologists and economists in the analysis of innovation processes.

\section{Development and Introduction of the "Killed Virus" Polio Vaccine 1952-1960}

The early years of polio vaccine development were characterized not only by personal animosity between two of the principal actors (Salk and Sabin) but also by widespread disagreement among experts regarding the relative merits of a "killed" or "inactivated" virus vaccine and a "weakened" or "attenuated" one. Jonas Salk, at the University

\footnotetext{
${ }^{11} \mathrm{~J}$ Rogers Hollingsworth, J Hage and R A Hanneman, State intervention in medical care: consequences for Britain, France, Sweden and the United States, 1890-1970, Ithaca and London, Cornell University Press, 1990.

${ }^{12}$ Ibid., p. 122.

${ }^{13}$ D J Rothman, Beginnings count: the technological imperative in American health care, New York, Oxford University Press, 1997.
}

\footnotetext{
${ }^{14}$ Ibid., p. 13.

${ }^{15} \mathrm{P}$ A David, "Clio and the economics of QWERTY', Am. Econ. Rev., 1985, 75, Papers and proceedings, pp. 332-7.

${ }^{16}$ Historical studies of polio vaccines have tended to focus on the United States, where the vaccines were developed. Little attention has been paid to their introduction and use in Europe.
} 


\section{Polio Vaccine Innovation and Adoption}

of Pittsburgh, chose to try to develop an inactivated virus vaccine. The more common view was that such a vaccine would not be adequate: that it would provide only a few months' protection. Nevertheless, with support from the National Foundation for Infantile Paralysis (later the March of Dimes) Salk pushed ahead. By late 1952 it was decided that the Salk vaccine was ready for a large-scale trial, and in April 1954 the US Public Health Service approved the trial. In April 1955, surrounded by cameras, hordes of reporters, and floodlights, the director of the trial, epidemiologist Thomas Francis, presented the results. The conclusion was that the vaccine was over 90 per cent effective against Types II and III, and 60 to 70 per cent effective against Type I polio virus. Whatever the proponents of an attenuated vaccine might have thought, the American nation breathed a sigh of relief. Within two hours the Salk vaccine was licensed for use. In 1955 five million American children would have to be vaccinated.

Immediately, discussion of the desirability of polio vaccination began in many countries. In Denmark, which had been shaken by an epidemic of unprecedented severity in 1952 , action was rapid. Experts from the Danish State Serum Institute had already been in touch with Salk and the Institute quickly set about vaccine production. Other European countries moved more cautiously. A serious set-back was the so-called Cutter incident that occurred shortly after the start of vaccination in the USA. Several children had become paralysed as a result, it was concluded, of vaccine produced by one of the US manufacturers, the Cutter company. The US Surgeon-General decided to take the Cutter vaccine off the market. However, even after close examination of the Cutter procedures it was not immediately clear what had caused the accident. Only later was it discovered that the problem was a technical one associated with the filtration process. In May 1955 the US vaccination programme was briefly suspended because of the accident. Public faith in the Salk vaccine was severely shaken. However, after a short delay, vaccination was resumed in the United States, and after the first year the US vaccination programme was seen as a big success.

\section{IPV in the Netherlands}

The Dutch Health Council (Gezondheidsraad) immediately established a "Polio committee" to advise on the relevance for the Netherlands of the newly available vaccine. It met for the first time in May 1955. In reports produced in June 1955 and May 1956 the committee expressed doubts as to the adequacy of the Salk vaccine. Adequate immunity, they advised, could be provided only by a vaccine containing live (attenuated) virus. Moreover, in the US children of seven to eight years of age were being vaccinated, whilst in the Netherlands children of five years and younger were eligible for vaccination. The Minister of Health was advised not to permit import of the vaccine for routine use: advice which he followed. However, in 1956 the country experienced a serious polio epidemic: 2,206 cases were recorded, of which 1,784 were paralytic. That fact, combined with the clear evidence of what had been achieved in the USA, led to a change of heart in the committee. By December it had decided that mass vaccination, on a voluntary basis and under the auspices of and at the cost of the government, was necessary. In the same month (December 1956) the Dutch Minister of Health announced that import of polio vaccine 


\section{Ulrike Lindner and Stuart S Blume}

would be permitted ${ }^{17}$ and free vaccination against polio offered to all children up to fourteen years of age.

The Minister invited the Health Inspectorate to develop a plan for national polio vaccination, in collaboration with the Association of Local Authorities in the Netherlands, and a number of other organizations. Establishing collaboration between local authorities, local health services and doctors in the form of regional vaccination authorities (entadministraties), under the supervision of the national Health Inspectorates, would ensure standard practices, schedules and monitoring across the country. It is important that the Netherlands already had a well-established vaccination system. Since 1953 Dutch children had been offered vaccination against diphtheria, tetanus and whooping cough, without charge. Implementation, however, was in the hands of a wide variety of organizations, differing significantly from one area of the country to another. Central coordination and surveillance, previously weak, were strengthened with the establishment of a national vaccination programme under the Ministry of Health in 1957. All children were to be given DKT (a combination of vaccines against the bacterial infections diphtheria, pertussis and tetanus), and - separately - the Salk polio vaccine. Vaccinations were free and, out of respect for the objections of Orthodox Protestant groups to vaccination, ${ }^{18}$ non-compulsory. Responsibility for the actual vaccinations was in the hands of the child welfare clinics, and supervised by the regional vaccination authorities.

When the Netherlands started its national vaccination programme in 1957, the combined vaccine against diphtheria, pertussis and tetanus (DPT, in Dutch DKT) was produced by a state institute, the Rijksinstituut voor Volksgezondheid (RIV), that already had considerable experience in the production of bacterial vaccines. Production of DKT on the scale needed had posed technical problems that could not be solved with the skills available in the Institute. Investments in new technology, and in personnel to develop it, had already been made. Although initial supplies of polio vaccine had been purchased abroad, in 1957 the government decided that the country should produce the vaccine itself. The RIV immediately set to work, preparing to establish a polio vaccine laboratory. Using new processing technology that it had developed itself, within a relatively short time RIV had an efficient and effective system for the production of polio virus. By combining the polio vaccine with the DKT, thought Hans Cohen (head of vaccine production at RIV, and later director of the Institute), it ought to be possible to increase vaccination coverage, since only four injections would be required in place of the previous seven or eight (four times DKT plus three or four times IPV). Thus, a start was made, in parallel, with development of a combination DKTP vaccine. By the end of 1958 sufficient combination DKTP vaccine had been produced for a trial to be held in the city of Leeuwarden. ${ }^{19}$ By 1960, 1.1 million doses

\footnotetext{
${ }^{17}$ It was decided that vaccine would not be imported from the USA, because the standards that IPV was required to meet in that country were felt to be inadequate and manufacturers had their hands full meeting domestic need (which could lead to problems in supply). A Belgian producer was selected by the RIV. See H Cohen and R Hofman, letter to the Editor, Nederlands Tijdschrift voor Geneeskunde, 2002, 146: 2454.
}

\footnotetext{
${ }^{18}$ The basis of these religious objections, and their effect on Dutch legislation relating to vaccination, are described in detail in P F Maas, Parlement \& Polio, 's-Gravenhage, SDU-uitgeverij, 1988, esp. pp. 35-51.

${ }^{19}$ We are grateful to Dr R J F Burgmeijer, medical director of the National Vaccination Programme, for help with the facts contained in this paragraph.
} 


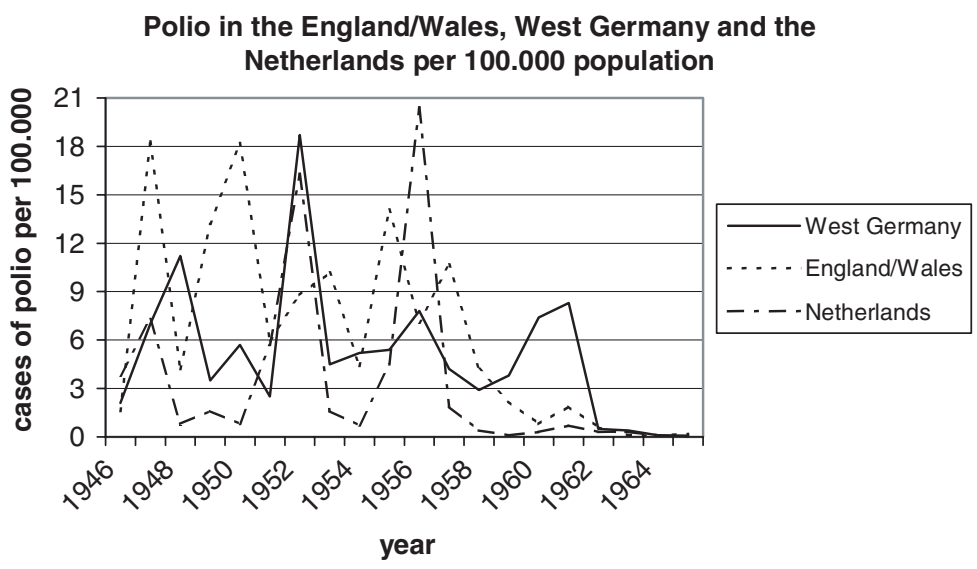

of DKTP had been produced: sufficient for an annual cohort of babies. After further trials, aimed at assessing negative reactions to the vaccine, had been conducted in 1961, the new combination vaccine was ready to be introduced on a national scale. In 1962 the combined vaccine replaced the separate DKT and IPV vaccines in the national vaccination programme. It is important to note that this programme was very effective from its beginning. By 1960, 87 per cent of children born between 1945 and 1957 had been vaccinated with IPV. The number of reported cases of polio fell dramatically, from 203 in 1957 to around 10 in the years after 1965 (see Figures 1 and 2).

\section{IPV in West Germany}

The situation in Germany in the mid- to late 1950s was different in a number of vital respects. For one thing, leading German health officials and scientists seemed to be quite distrustful of US vaccine research in general, a scepticism which was reinforced after the Cutter incident in late spring 1955. Highly unorthodox theories regarding polio were put forward by authoritative spokesmen and received serious attention. ${ }^{20}$ For example Franz Redeker (director of the health department in the Ministry of the Interior) declared in September 1955 that IPV-inoculated children would disseminate polio and therefore could infect non-vaccinated children. He even said the danger of being infected by "wild" polio would be no greater than the danger of being infected by vaccination. ${ }^{21}$ No less unorthodox, Professor Georg Henneberg, a German immunologist and at that time head of the Robert Koch Institute in Berlin, stated at a meeting of polio experts in 1956 that Germany had a less aggressive polio virus than that in the United States. Germany therefore had no

\footnotetext{
${ }^{20}$ G Henneberg, 'Zum Problem der Poliomyelitisschutzimpfung in Deutschland', Der öfentliche Gesundheitsdienst, 1956/57, 18: 181-7.
}

\footnotetext{
${ }^{21}$ Bundesarchiv Koblenz (BAK), B 142/22, Vermerk, 30 Sept. 1955.
} 


\section{Ulrike Lindner and Stuart S Blume}

\section{Figure 2}

Polio cases in the Netherlands per 100,000 population ${ }^{\text {a }}$

\begin{tabular}{l|l|l|l|l|l|l|l|l|l|l} 
Year & 1946 & 1947 & 1948 & 1949 & 1950 & 1951 & 1952 & 1953 & 1954 & 1955 \\
\hline $\begin{array}{l}\text { Cases of } \\
\text { acute polio }\end{array}$ & 3.8 & 7.3 & 0.8 & 1.6 & 0.8 & 5.7 & 16.3 & 1.6 & 0.7 & 4.5 \\
\hline Year & 1956 & 1957 & 1958 & 1959 & 1960 & 1961 & 1962 & 1963 & 1964 & 1965 \\
\hline $\begin{array}{l}\text { Cases of } \\
\text { acute polio }\end{array}$ & 20.4 & 1.9 & 0.4 & 0.1 & 0.3 & 0.7 & 0.3 & 0.3 & 0.1 & 0.02
\end{tabular}

Polio cases in West Germany per 100,000 population ${ }^{\mathrm{b}}$

\begin{tabular}{l|l|l|l|l|l|l|l|l|l|l} 
Year & 1946 & 1947 & 1948 & 1949 & 1950 & 1951 & 1952 & 1953 & 1954 & 1955 \\
\hline $\begin{array}{l}\text { Cases of } \\
\text { acute polio }\end{array}$ & 2.1 & 7.0 & 11.2 & 3.5 & 5.7 & 2.5 & 18.7 & 4.5 & 5.2 & 5.4 \\
\hline Year & 1956 & 1957 & 1958 & 1959 & 1960 & 1961 & 1962 & 1963 & 1964 & 1965 \\
\hline $\begin{array}{l}\text { Cases of } \\
\text { acute polio }\end{array}$ & 7.8 & 4.2 & 2.9 & 3.8 & 7.4 & 8.3 & 0.5 & 0.4 & 0.1 & 0.08
\end{tabular}

Polio cases in England and Wales per 100,000 population ${ }^{c}$

\begin{tabular}{l|c|c|c|c|c|c|c|c|c|c} 
Year & 1946 & 1947 & 1948 & 1949 & 1950 & 1951 & 1952 & 1953 & 1954 & 1955 \\
\hline $\begin{array}{l}\text { Cases of } \\
\text { acute polio }\end{array}$ & 1.6 & 18.3 & 4.2 & 13.2 & 18.2 & 6.0 & 8.8 & 10.2 & 4.4 & 14.1 \\
\hline Year & 1956 & 1957 & 1958 & 1959 & 1960 & 1961 & 1962 & 1963 & 1964 & 1965 \\
\hline $\begin{array}{l}\text { Cases of } \\
\text { acute polio }\end{array}$ & 7.1 & 10.7 & 4.2 & 2.2 & 0.8 & 1.9 & 0.6 & 0.1 & 0.08 & 0.2
\end{tabular}

\footnotetext{
${ }^{\mathrm{a}} \mathrm{R}$ J F Burgmeijer and D J A Bolscher, Vaccinaties bij kinderen, 4th ed., Assen, Koninklijke Van Gorcum, 2002; and Statistisch jaarboek for population numbers.

${ }^{\mathrm{b}}$ Until 1960 numbers without West Berlin, from 1961 onwards with West Berlin. Statistik der Bundesrepublik Deutschland, Gesundheitswesen, 1946-50, p. 18; 1951, p. 39; 1952, p. 51; 1953, p. $34 ; 1954$, p. $33 ; 1955$, p. $33 ; 1956$, p. $24 ; 1957$, p. $22 ; 1958$, p. 23 ; Statistisches Bundesamt, Fachserie A: Bevölkerung und Kultur, Reihe 7, Gesundheitswesen, 1960, p. 41; 1962, p. 27; 1964, p. 52; 1970, p. 78; and Statistisches Bundesamt, Statistisches Jahrbuch for population numbers.

${ }^{\mathrm{c}}$ The table includes the numbers of polio cases in England and Wales; Scotland is not included. Reports of the Chief Medical Officer on the state of the public health, 1947, PP 1948-49, XVI, p. 40; 1951, PP 1952-53, XIII, p. 40; 1957, PP 1958-59, XV, p. 52; 1961, PP 1962-63, XIX, p. 44; Gesundheitswesen, 1970, p. 78 and Annual Abstract of Statistics for population numbers.
} 


\section{Polio Vaccine Innovation and Adoption}

need of mass vaccination. It would be more advisable to wait for a "natural immunity" against polio, which would develop in due course. Lacking any data or evidence to support this view, he nevertheless discussed his theories openly at a conference with Thomas Francis, who had been responsible for the IPV trials in the USA. ${ }^{22}$ Whilst there were other German scientists who supported a quick IPV vaccination programme, these strongly sceptical views prevailed at the highest level. ${ }^{23}$ At the same time, the public discourse remained muted: a strong interest in the new IPV vaccination did not develop; there was no significant pressure from the public on health politicians to introduce the new vaccine. Equally, when vaccination was finally introduced in 1958, the response of the public was not enthusiastic. ${ }^{24}$

From 1957 onwards, however, a slight change can be observed in the attitudes of scientists and health politicians: several German scientists now reported regularly at the International and European Polio Conferences. ${ }^{25}$ Their concern about the poor West German position in the international fight against polio grew; at the same time, their mistrust of the new vaccines gradually faded in the face of the successful introduction of these in other European countries. Also, the peculiar theories about immunization processes were no longer mentioned. ${ }^{26}$

However, whereas the Netherlands was rapidly developing a tightly integrated and centrally organized vaccination programme, Germany had a loosely organized and patchy one. After the Second Word War, the German public health system was de-centralized and organized at the Länder (individual state) level. The health authorities never succeeded in rebuilding the strong health service that had existed in the years of the Weimar Republic. ${ }^{27}$ In the 1950s, West Germany had no Ministry of Health at the federal level, only a department within the Ministry of the Interior, and most public health issues were dealt with at the level of the individual states. This meant that vaccination was under the control of the individual Länder and their ministries: they had to license vaccines, to import vaccines, to issue laws or decrees on how to deal with vaccination. Coordinating institutions existed, to be sure. These included the Bundesgesundheitsrat, a federal

\footnotetext{
${ }^{22}$ BAK, B 142/22, Protokoll Wiesbadner Symposium der 'Ventnor-Foundation', 2 June 1956; see also 'Robert-Koch-Institut - Tradition und Fortschritt', Epidemiologisches Bulletin, 2000, no. 39, pp. 311-18.

${ }^{23}$ There was a widespread scientific discourse on polio therapy in West Germany, but almost no publications on polio vaccines, since research in the FRG on vaccination was negligible. Der offentliche Gesundheitsdienst, the official journal of the German Association for the Fight against Polio, had only one original article on virological issues before 1960, see also details in R Wohlrab, 'Praktische Anwendung neuester virologischer Untersuchungen', Der öfentliche Gesundheitsdienst, 1959/60, 21: 558-74. Therefore the scientific discourse on polio vaccination was dominated by only a few people such as the health politician Franz Redeker and the immunologist Georg Henneberg.
}

\footnotetext{
${ }^{24}$ BAK, B 142/23, Referat Dr Lundt über die
} Impfungen gegen Poliomyelitis in der Bundesrepublik Deutschland, Sept. 1958.

${ }^{25}$ For the change in attitudes, see, for example, reports of German delegates at the European Poliomyelitis-Symposiums in 1958 and 1960: BAK, B 142/23, Bericht Poliomyelitis-Symposium Madrid für das Innenministerium, 1958; Vorarchiv Arbeitsministerium NRW, 1200, Sitzung, 7 April 1960.

${ }^{26}$ For the more positive attitude in West German ministries and councils in 1957/58, see Vorarchiv Arbeitsministerium NRW, 1200, Konferenz der für das Gesundheitswesen zuständigen Minister und Senatoren Berlin, 1 March 1957; BAK, B 142/23 Vermerk, 5 Sept. 1959.

${ }^{27}$ L v. Manger-Koenig, 'Der öffentliche Gesundheitsdienst zwischen Gestern und Morgen', Das öffentliche Gesundheitswesen, 1975, 37: 433-8. 


\section{Ulrike Lindner and Stuart S Blume}

committee for public health, and a committee of Länder health ministers. However, even if the minister and leading medical officers of the Länder met regularly at national level, it was still very difficult to organize a co-ordinated public health service. ${ }^{28}$ As an outcome of these problems, IPV vaccination was introduced unevenly. Most of the Länder (including Bavaria) charged fees, whilst a few (including North-Rhine-Westphalia) gave out vaccine for free. No coherent official programme regarding vaccination had been developed and there was no national campaign designed to encourage it. Nor was there any powerful pressure group supporting vaccination. The German Association for the Fight against Polio (Deutsche Vereinigung zur Bekämpfung der Kinderlähmung) acted quite cautiously and was not dominated by patients but by the same health officials and scientists who took the decisions at the Länder and federal levels. ${ }^{29}$ In contrast to the National Vaccination Programme in the Netherlands, the weak, de-centralized and disorganized German health system seemed ill-equipped to carry out a complicated vaccination process.

A third difference concerned vaccine production. Whereas in the Netherlands IPV was produced by a state institute, RIV, which functioned under the responsibility of the Ministry of Health, vaccine in Germany was produced by a private company, Behringwerke (part of Hoechst AG), located in Marburg. ${ }^{30}$ Relations between the sole manufacturer of IPV in Germany and public health authorities proved to be difficult. The first German Land, Hesse, where Behringwerke was located, had approved the production for vaccination very early and had allowed vaccination in some children's hospitals in spring 1955. However, vaccination was stopped again soon afterwards. ${ }^{31}$ In April 1955, the members of the Bundesgesundheitsamt, the central federal office for research in medicine/ public health, were not permitted to enter the company's production laboratory. Behringwerke accused them of industrial espionage. This behaviour resulted in growing mistrust in the health administration at both Länder and federal levels and was one reason for the rapid termination of vaccination in Hesse. Other events added to the strained relationship between the two, which also furthered the slow introduction of IPV in West Germany. From 1958 onwards, however, Behringwerke was producing sufficient IPV for German requirements and the relationship between the health administration and the company seemed to have improved.

To summarize: IPV was never successfully implemented in Germany and reached only 5 per cent of the population in 1960 . Why was there no determined commitment to IPV in Germany? The dominant view at the time was that the public simply did not accept the IPV vaccine and that nothing could be done by the state and the administration. ${ }^{32}$ In reality there was a more complicated interplay of factors and tensions between user, state, market and

\footnotetext{
${ }^{28}$ BAK, B 142/22, Protokoll über die Besprechung der leitenden Medizinalbeamten der Länder, 10 Feb. 1956.

${ }^{29}$ U Lindner, Gesundheitspolitik in der Nachkriegszeit. Großbritannien und die Bundesrepublik Deutschland im Vergleich, Munich, Oldenbourg, 2004, pp. 239-40.

${ }^{30} \mathrm{~W}$ Bartmann, Zwischen Tradition und Fortschritt. Aus der Geschichte der Pharmabereiche von Bayer, Höchst und Schering von 1935-1975, Stuttgart, Franz Steiner, 2003.
}

${ }^{31}$ BAK, B 142/22, Protokoll über die Besprechung mit den Leitenden Medizinalbeamten der Länder, 10. Feb. 1956; Die Schutzimpfung gegen Poliomyelitis, Behringwerk-Mitteilungen, Heft 31, Marburg a.d. Lahn, Elwert, 1956, p. 258.

${ }^{32}$ Statement of the Minister for Health, Dr Elisabeth Schwarzhaupt, Verhandlungen des Deutschen Bundestages, 4. Wahlperiode, 26. Meeting, 12 April 1962, p. 1069. 


\section{Polio Vaccine Innovation and Adoption}

technology that made Germany react cautiously towards IPV, delaying its implementation until 1957. Then, the Länder developed their individual programmes to provide IPV vaccine for citizens. Furthermore, the long discussions between 1955 and 1957 in the scientific community, dominated by the alleged risks of IPV vaccination, did nothing to increase public trust in the vaccine. By 1958 it was becoming clear that the FRG was falling behind other European countries in bringing polio under control. But even then, the German state did not immediately introduce new programmes to speed up IPV vaccination. Accordingly, the number of polio cases remained high until 1961/62, when OPV was eventually introduced (see Figure 1).

\section{$I P V$ in the $U K$}

The British response to IPV was different again. Virological research on polio and polio vaccines had been slow and weak during the 1940s and the beginning of the 1950 s. $^{33}$ In contrast to West Germany, UK health officials were not mistrustful of American research. On the contrary, they had high hopes of Salk's IPV vaccine and the planned US field trials in 1954. Sir Weldon Dalrymple-Champneys was sent by the Ministry of Health for England and Wales to the United States in 1954 to attend these trails. He returned enthusiastic about the possibilities of the new vaccine. The Ministry of Health prepared vaccinations for spring $1955 .{ }^{34}$ Children from Sheffield, Manchester and London would be inoculated first and then tested for their serological reaction.

In the UK there was no state institute to produce the vaccine as there was in the Netherlands, but - as in West Germany-private producers worked together with the health administration. However, since the main producer of vaccine in Britain, the pharmaceutical company Glaxo, could not produce enough vaccine in time, the British trials were delayed. ${ }^{35}$

When some weeks later the Cutter incident in the USA became known, the British vaccination project was stopped immediately. Some of those who had been enthusiastic advocates, such as Dalrymple-Champneys, now became sceptical. ${ }^{36}$ Both the Medical Research Committee and the Joint Committee on Poliomyelitis Vaccine advised against the importation of US-produced Salk-vaccine. In the UK, vaccine made from the virulent Mahoney strain (as was the US Salk-vaccine) was forbidden. However, Glaxo could not produce vaccine made from different virus strains in sufficient quantities so quickly. This meant a further delay in the vaccination programme. There were no more vaccinations in 1955. ${ }^{37}$ The Ministry of Health and especially the Medical Research Council moved cautiously during the next two years, even though the Cutter incident had been cleared

\footnotetext{
${ }^{33}$ National Archives (NA), Public Record Office (PRO), MH 55/1769, Infantile Paralysis Fellowship to Minister of Health, 27 Sept. 1951.

${ }^{34}$ Wellcome Library, London, Archives and Manuscripts, GC 139, F 22.

${ }^{35}$ Report of the Chief Medical Officer on the state of the public health, 1955, PP 1956-57, XIII, p. 77.
}

\footnotetext{
36 'Poliomyelitis vaccine trials deferred', $B r$. med. J., 1955, i: 1535; T Gould, A summer plague: polio and its survivors, New Haven and London, Yale University Press, 1995, p. 160.

${ }^{37}$ NA, PRO, MH 133/467, Joint Committee on Poliomyelitis Vaccine, Meeting 13 July 1955; Joint Committee on Polio Vaccine to Senior Administrative Medical Officers, 16 Aug. 1955.
} 


\section{Ulrike Lindner and Stuart S Blume}

up and the United States vaccinated millions of children successfully with vaccine made from the Mahoney strains in 1955 and 1956.

Eventually, in 1956, a new vaccination programme was planned with British IPV, made from the Brunhilde strain, which was thought less aggressive than the Mahoney strain. ${ }^{38}$ However, only small amounts of vaccine were available from the British manufacturer. In May and June 1956 the vaccine was administered to children between two and nine years of age, whose parents had to register them beforehand. ${ }^{39}$ On the whole, 29 per cent of all British children in that age group had been registered for vaccination, but only 10 per cent of those registered, or 3 per cent of all children born between 1947 and 1956, could be inoculated in 1956 with the specified two injections. The limited supplies available extended no further than this.

Why did the British attitude, which had been so much in favour of the Salk vaccine, change so quickly in 1955 and why were the risks so radically reassessed that for two years imports of US vaccine were impossible? Consonant with Bryder's findings regarding the introduction of the BCG vaccine, historians connect the cautious attitude of the health administration in the case of polio vaccines with the long history of British anti-vaccination movements and a general public distrust in vaccination. ${ }^{40}$ However, this cautious attitude must have been the outcome of a more complex relationship between health administration, pharmaceutical companies and users. An additional source of delay had to do with the supply of vaccine. For spring 1957, Glaxo had promised to put a certain amount of vaccine at the disposal of the health ministry, but there were again delays in production. In the meantime, criticism of the Ministry of Health grew, with many articles in specialist literature and in the press demanding the importation of American vaccine in order to inoculate sufficient numbers of children. Growing public pressure for vaccination was a main factor leading to a change of views in the British health administration. By mid-1957, the 1955 decision not to import US vaccine with Mahoney strains because of the Cutter accident was seen as outdated. In July 1957 the Medical Research Council revised its position and recommended imports for 1958, though with the proviso that all imported vaccine be submitted to extra tests in Britain. ${ }^{41}$ Following this change of attitude in the MRC, the cabinet now agreed to buy American and Canadian vaccine, and contracts were made with the Canadian Connaught Laboratories and the US based Pitman-Moore company. $^{42}$

Government hesitancy seems to have reflected not only concerns over safety. In the Ministry of Health the question "If British supplies are adequate, should we buy only

\footnotetext{
${ }^{38}$ NA, PRO, MH 133/467, Joint Committee on Poliomyelitis Vaccine Meeting, 10 Oct. 1955.

39 'Medical notes in Parliament: Poliomyelitis vaccine', Br. med. J., 1956, i: 299.

${ }^{40} \mathrm{C}$ Webster, The health services since the war. Vol. 2: Government and health care: the National Health Service 1958-1979, London, The Stationary Office, 1996, pp. 27, 128-9; A Hardy, 'Poliomyelitis and the neurologists: the view from England, 18961966', Bull. Hist. Med., 1997, 71: 249-72; for the antivaccination movements in Britain, see N Durbach, Bodily matters: the anti-vaccination movement in England 1853-1907, Durham, NC, Duke University
}

Press, 2005, and for post-1945 development, especially pp. $200-7$.

${ }^{41}$ NA, PRO, MH 55/2462, County Councils Association to Enid Russel-Smith, Ministry of Health, Sept. 1957. For the public discussion, see articles with headings as "Three shots needed" or "We're $7,000,000$ jabs short, yet there is plenty of Salk vaccine in the US and Canada" in the Daily Express, the Star and other British newspapers during the winter of $1957 / 58$.

${ }^{42}$ Report of the Chief Medical Officer on the state of public health, 1957, PP 1958-59, XV, pp. 85-6. 


\section{Polio Vaccine Innovation and Adoption}

British?" was discussed repeatedly in November and December 1958. Although Canadian and American products were much cheaper ( $£ 107$ to $£ 117$ per litre compared with $£ 125$ to $£ 175$ for vaccine made by British companies) and should therefore have been attractive to the NHS with its chronic shortage of funds, other criteria could clearly override cost considerations. These were partly to do with safety. The MRC still saw British vaccine as the safest (without giving any sound medical reasons), but the "natural desire to use British rather than foreign products", as stressed in the British ministry, clearly involved more than this. ${ }^{43}$ For 1958 the Ministry of Health agreed to administer vaccine to all children under fifteen. In order to meet this goal the imported vaccine would be used, provided it had undergone an additional British test. Furthermore, parents should be able to choose, and would have the right to refuse to allow their children to be inoculated with imported vaccine. This complicated scheme added to the relatively slow progress of vaccination in the $\mathrm{UK} .^{44}$

Once sufficient quantities of vaccine were available, vaccination proceeded smoothly. In contrast to West Germany and comparably with the Netherlands, the co-ordination and organization of vaccination was good in the centrally organized National Health Service. The Ministry of Health started centrally organized publicity campaigns: easy to arrange in a centralized health service (in contrast to that in West Germany). ${ }^{45}$ Vaccination was organized and carried out by the Local Health Authorities (LHAs). ${ }^{46}$ With their central organization they could be easily informed about new developments by the Ministry of Health. Medical Officers of Health and other personnel of the LHAs took over the inoculation programmes; occasionally GPs collaborated. Like all treatment and preventive measures, vaccination was free under the NHS. That the LHAs were accepted and trusted by the public as places offering preventive services helped acceptance of the vaccine.

In Britain, problems and delays cannot be attributed to weak organization of the public health system. They had more to do with the cautious attitudes of the health authorities and problems in ensuring the necessary supply of vaccine. In any event, imported supplies finally allowed for extension of the vaccination programme in 1958. By the end of the year, 6.4 million people had had two inoculations ${ }^{47}$ and the number of polio cases declined rapidly thereafter. By 1960 the low incidence of disease could be taken as showing the efficiency of the IPV vaccination programme in Britain (see Figure 1).

\section{Responses to the Live Virus Vaccines in the 1960s}

In the mid-1950s Albert Sabin at the University of Cincinnati and Harold Cox and Hilary Koprowski (both at that time with the pharmaceutical company Lederle), who had never believed in the killed vaccine, were working on attenuated polio vaccines. By 1956, largescale trials of attenuated vaccines were being planned. These could not be held in the USA. Widespread use of the Salk vaccine meant that most children already had antibody levels

\footnotetext{
${ }^{43}$ NA, PRO, MH 55/2464, Poliomyelitis Vaccine-Ordering Policy, 1958.

${ }^{44}$ NA, PRO, MH 55/2462, Enid Russel-Smith, Ministry of Health to Mr Dacey, County Councils Association, 27 Sept. 1957.

${ }^{45}$ NA, PRO, MH 55/2212, Heald to Dodds, 15 Oct. 1958.
}

\footnotetext{
${ }^{46}$ NA, PRO, MH 55/2469, Memorandum on Poliomyelitis Vaccine, 9 May 1960.

${ }^{47}$ Report of the Chief Medical Officer on the state of public health, 1958, PP 1959-60, XVI, p. 82.
} 


\section{Ulrike Lindner and Stuart S Blume}

that were too high for a different vaccine to be tested. At the invitation of George Dick, professor of microbiology in Belfast, a first trial of Koprowski's vaccine was organized in Northern Ireland, followed by one in the Belgian Congo.

Albert Sabin, himself of Russian birth, succeeded in having his vaccine tested on a huge scale in the Soviet Union: nearly 15 million people had swallowed his vaccine by July $1960 .^{48}$ The American authorities, unwilling to be once more rushed into licensing (as they felt they had been with the Salk vaccine), were concerned by the possibility of the attenuated virus vaccine reverting to virulence. Joseph Melnick, professor of virology and epidemiology at Baylor University, was asked to conduct a comparative study of the Sabin and Cox vaccines. Melnick's results clearly favoured the Sabin strains over those of Lederle-Cox. ${ }^{49}$

In August 1960, the US Surgeon-General announced that he would recommend licensing the Sabin vaccine, despite the protests of the National Foundation for Infantile Paralysis to the effect that the efficacy of the Salk vaccine had not yet been fully established. On the same day, "Lederle made it known that it had contracted to manufacture Sabin vaccine" ${ }^{50}$ The vaccine was, in fact, licensed on a strain-by-strain basis: in August 1961 Pfizer was granted a licence to produce and market a Type I vaccine, Type II followed in October, and Type III in March 1962. A trivalent vaccine, including all three types, became available in 1963. The stage was set for protracted discussion of the relative merits of the Salk and Sabin vaccines.

At the beginning of the 1960s a clear professional consensus in favour of OPV emerged. OPV was believed to confer longer-lasting protection, to be more acceptable to the public, quicker acting, and to provide indirect protection to those not vaccinated through excretion of live vaccine by those who had been vaccinated. Given these advantages, it was believed that OPV would be far more effective in combating an epidemic. In the course of the 1960s, paralleling growing medical preference, pharmaceutical companies slowly abandoned IPV manufacture. However, the suspicion that in a small number of cases attenuated virus in the live virus vaccine could revert to virulence and give rise to vaccine-induced polio, rendered the arguments more complex. ${ }^{51}$

It was gradually acknowledged that, in a small but unknown percentage of cases, the live polio virus in OPV reverted to virulence. Studies in the USA had found that a small number of polio cases had been caused by the vaccine itself. This was not the failure of one company's production process, as had occurred with IPV some years before. It was a risk inherent in use of the vaccine. Choosing between one vaccine or the other now entailed balancing relative benefits against relative risks: the presumed greater benefits of OPV

\footnotetext{
48 "Though no one questioned the overall success of Sabin's mission in Russia, it was, as Smorodintsev belatedly admitted during a visit to the United States in 1964 'a public-health measure not a field trial'. Sabin's live vaccine was never subjected to the kind of rigorous field trial that Salk's killed vaccine had undergone in 1954", Gould, op. cit., note 36 above, p. 183.

${ }^{49}$ J L Melnick and J C Brennan, 'Monkey neurovirulence of attenuated poliovirus vaccines being used in field trials', in Live poliovirus vaccines,
}

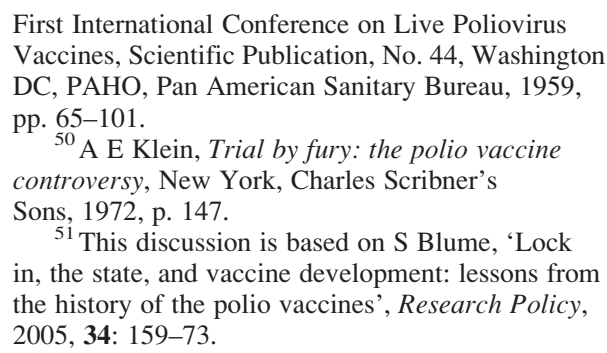




\section{Polio Vaccine Innovation and Adoption}

(greater acceptability, community protection and so on) against the small but definite risks associated with its use. Were the risks acceptable, and should society take them? Posed in this way, the issue was a political one in a very fundamental sense. Perceptions might well depend on how successful reduction in the incidence of polio with IPV had been andperhaps still more importantly—what still needed to be accomplished.

With the licensing of OPV, discussion began anew in the three countries, though with very different results.

\section{$O P V$ in the Netherlands}

Opinion was divided in the polio committee of the Dutch Health Council. In 1960-61 no one argued that Salk vaccine should be replaced by Sabin vaccine, but some believed that a store of Sabin vaccine should be available for use in the event of an epidemic. In 1962 this became government policy: Sabin vaccine could be imported for use in an emergency. Discussion regarding basic vaccination continued unabated. In late 1962 the polio committee once more reported to the Minister, recommending that Salk vaccine remain the basis of the programme. This time $\mathrm{J} \mathrm{H}$ de Haas, professor of paediatrics, submitted a minority report in which he argued that OPV was more effective and that it was not advisable for the Netherlands to continue with IPV when virtually all countries had switched to OPV. In response, it was pointed out by the Chairman of the Health Council that there was no question of "isolation": Australia, Canada, Denmark, Sweden and France also continued to use IPV wholly or in part. In 1963 the Minister decided that the policy would remain unchanged. Largely due to religious objections to vaccination, the number of polio cases remained around 30 per year in some strongly Protestant communities. Given the advantages of passive immunity that the Sabin vaccine was believed to confer, and the possibility that there would be less objection to an oral (non-injected) vaccine, speculation continued as to whether the Sabin vaccine should be given to all children. In a 1964 report the polio committee was divided. In early 1965, however, it had reached a new consensus. Adducing two principal arguments, the committee now stated that there was no longer any reason for considering possible booster use of the Sabin vaccine. First, circulation of the virus had been substantially reduced, and probably permanently so. And second, they referred to evidence presented at the European Conference on Polio, held in Warsaw in 1964, that had emphasized the risks of the live vaccine. Despite questions from parliamentarians from time to time, ${ }^{52}$ and suggestions that the interests of the single national producer had played too great a role, the Netherlands continued exclusively to use IPV produced by the RIV, reserving imported OPV for emergency use in the event of an epidemic.

\section{OPV in Germany}

The introduction of live polio vaccine in West Germany was far from auspicious. Provoked by the beginnings of vaccination with Sabin vaccine in East Germany in April 1960, West Berlin (legally in a position to act independently of the West German

${ }^{52}$ Maas, op. cit., note 18 above, pp. 119-28. 


\section{Ulrike Lindner and Stuart S Blume}

government) began vaccination with live vaccine in May of the same year. The arguments were, with hindsight, curious ones. Berlin was still an open city in 1960. The health authorities feared, for example, that vaccinated people from East Berlin would infect people from the western part of the city. They even declared that it was necessary "to build up a wall against the vaccine virus by generating immunity in West Berlin". ${ }^{53}$ When the American company Lederle offered the city Cox live vaccine for free, the Berlin authorities accepted. 290,000 people were vaccinated from 11 May onwards. ${ }^{54}$ However, the vaccine proved to be too dangerous: forty-eight cases of polio ensued, and three people died. The vaccination programme was stopped. Despite this experience, in 1961 the Federal German government decided to initiate a national programme of vaccination using OPV — the Sabin vaccine.

Further developments in West Germany are interesting in a number of respects. First of all, public discussion remained again relatively muted. The grave consequences in Berlin did not lead to a public outcry in Germany or to a wide discussion in the press. Even after the cases of polio related to the vaccination programme were publicly known, Berlin health officials mainly stressed the fact that Berlin had fewer polio cases than the rest of West Germany and that the vaccination programme had to be seen as a success. The city's newspaper commentary was largely favourable. ${ }^{55}$ When the circumstances of the Berlin incidents were reported at the Fifth International Polio Conference in Copenhagen in July 1960 , German press coverage remained quite neutral. ${ }^{56}$ In the national scientific community mistrust of polio vaccination was abating. Even after the incidents in West Berlin were known, the scientific debate seemed to be in favour of the live vaccine. The clinical advantages of OPV were stressed in the arguments of the health officials: the easy application, the possibility of an easy mass vaccination and the lower costs. ${ }^{57}$ Reports of successful mass vaccination campaigns in the Eastern bloc presented at the 1960 International Polio Conference also added to the favourable image of the live vaccine. Concern at the risks of the new vaccine, which were evidently higher than the risks of IPV, did not dominate the scientific discourse as much as it had when IPV was introduced.

The interests of the German vaccine industry were not a crucial factor in the change of vaccination policy. Behringwerke had a clear commercial interest in promoting further their existing IPV vaccine and in intensifying IPV vaccination. This is not what happened. The company obviously had little influence on further decisions of the state administration in favour of OPV vaccine, as the first vaccination programme started with only imported OPV. For the first years of OPV vaccination the domestic manufacturer could not produce sufficient vaccine for West Germany.

${ }^{53}$ BAK, B 142/3677, Sitzung der

Arbeitsgemeinschaft der leitenden Medizinalbeamten der Länder, 7 April 1960, in Saarbrücken.

${ }^{54}$ See several articles in Berlin newspapers, for example, 'Auch Affen trinken Impf-Cocktail',

Berliner Morgenpost, 6 May 1960; 'Aktion gegen Kinderlähmung beginnt', Der Tagesspiegel, 10 May 1960.

${ }^{55}$ See 'Seit dem 10. Juli kein neuer Polio-Fall', Der Tagesspiegel, 30 July 1960; 'Beginnende Polio-Epidemie zum Stehen gebracht', Der Tagesspiegel, 2 Aug. 1960.

\footnotetext{
${ }^{56}$ There are no articles covering this incident in June or July 1960 in newspapers and journals throughout West Germany, such as the Frankfurter Allgemeine Zeitung, Die Zeit, and Der Spiegel. In July 1960 there were some articles reporting from the Copenhagen Conference, where German scientists referred to the incidents in Berlin, see Frankfurter Allgemeine Zeitung, 29 July 1960, no. 175.

${ }^{57}$ BAK, B 142/3527, Niederschrift über die Sitzung des Ausschusses 2 (Seuchenbekämpfung und Hygiene) des Bundesgesundheitsrates, 28/29 Sept. 1961.
} 


\section{Polio Vaccine Innovation and Adoption}

The German state and its health system changed vaccination policy quickly. Despite the grave problems in Berlin and the higher risks of OPV, the federal health administration decided to introduce vaccination with Sabin live vaccine in West Germany in $1961 .{ }^{58}$ An important reason for this decision was international pressure: the GDR had successfully and without serious incidents introduced mass vaccination with Sabin vaccine in 1960 and had vaccinated almost the whole population in the meantime. The competition between the two German states and Cold War politics brought West Germany to act quickly. ${ }^{59}$ Political and ideological arguments for OPV were now crucial. Moreover, these Cold War considerations coincided with growing international pressure. The poor position of West Germany in regard to IPV vaccination was by now a source of growing embarrassment for West German scientists and health officials. ${ }^{60}$ As a consequence, the national attitude towards new vaccine developments had already started to change. All in all, international influence seems to have overcome national inhibitions. What followed was a change not only in discourse, but in strategies.

The most striking change occurred in the organization of vaccination. Vaccination with live vaccine posed the possibility of contact infections of third persons. As this meant a potential violation of a person's integrity (guaranteed in the federal constitution), vaccination could not be initiated without legal provision. The federal state did not have the jurisdiction to pass such a law. ${ }^{61}$ In the case of OPV, the Länder, which had previously acted so slowly and cautiously, now issued laws immediately and started vaccination quickly. This time vaccination was organized via the public health administration only, and it was free. ${ }^{62}$ In the case of IPV most of the Länder had charged the users. Now the Länder paid enormous sums for the imported vaccine, because Behringwerke could not immediately produce enough OPV in $1962 .^{63}$

The vaccination was an immediate success; 23 million people were vaccinated in 1962 , the polio rates declining rapidly. ${ }^{64}$ In the case of the Länder major incentives for change were not only the rivalry with the East but also the rivalries among the Länder themselves. Every single Länder government was now obviously keen to be successful with vaccination at last and did not want to be a latecomer in this crucial development. In the case of OPV, slowly changing national attitudes were confronted by sudden political pressure due to Cold War politics resulting in a rapid revision of German vaccination policies. The changed international environment played a major role in the introduction of OPV.

\footnotetext{
${ }^{58}$ BAK, B 142/3527, Niederschrift über die Sitzung des Ausschusses 2 des Bundesgesundheitsrates, 28/29 Sept. 1961, in Bonn.

${ }^{59}$ See the meeting of the leading health officers of the West German Länder when the GDR had started mass vaccination: BAK, B 142/3677,

Sitzung der Arbeitsgemeinschaft der leitenden Medizinalbeamten der Länder, April 1960.

${ }^{60}$ See report of the West German delegate at the European Polio Symposium in 1961: BAK, B 142/23, Bericht für das Innenministerium, VII. Europäisches Poliomyelitis Symposion, in Oxford, Sept. 1961.

${ }^{61}$ BAK, B 142/3677, Sitzung der für das Gesundheitswesen zuständigen Minister und
}

Senatoren, 20.12.1961 in Bonn; W P Kierski, 'Polio-Gesetzgebung', Gesundheitspolitik, 1962, 4: $97-105$.

${ }^{62}$ Verhandlungen des deutschen Bundestages, Stenographische Berichte, 4. Wahlperiode, 12 April 1962, p. 1069.

${ }^{63}$ BAK, B 142/23, Vermerk zur Sitzung der Arbeitsgemeinschaften der Leitenden Medizinalbeamten der Länder, 2/3 May 1962, in Nürnberg.

${ }^{64}$ 'Stand der Poliomyelitis-Schutzimpfung in den europäischen Ländern', Der öffentliche Gesundheitsdienst, 1964, 26: 105-11. 


\section{Ulrike Lindner and Stuart S Blume}

\section{$O P V$ in the $U K$}

In the UK, as in West Germany, OPV had a bad start. The microbiologist George Dick had tested Koprowski's live vaccine in Northern Ireland in 1956. His small trials had disastrous results, showing Koprowski's vaccine to be highly virulent. From then on Dick, who had a high standing in the British scientific community, was a strong critic of the live virus principle. It is no wonder that the Joint Committee on Poliomyelitis Vaccine generally rejected the new OPV vaccine in $1959 .{ }^{65}$ The committee members mainly feared that the virus would revert to virulence in the human body and would pose a risk to non-vaccinated third persons. The risks of the live vaccine dominated the scientific discussion in Britain until 1960.

From mid-1960 onwards, however, the discussion changed. Some months later than in West Germany, OPV came to be seen as a possible alternative. For British participants too, discussions at the Fifth International Polio Conference in Copenhagen in July 1960 played their part. ${ }^{66}$ Like the Dutch and in contrast to the Germans, the British had a working IPV programme and polio incidence was already declining rapidly. But compared to the Netherlands, which had rejected OPV, the clinical advantages of the new Sabin vaccine received much more emphasis in British discussions.

An important consideration seems to have been the American decision regarding the new vaccine. British health officials waited on reactions in the US:

Until last week the United States have had an exceedingly conservative approach to the use of Sabin vaccine on a large scale. However, the Surgeon General of the United States Public Health Service announced on $24^{\text {th }}$ Aug. 1960 that his organization was prepared to licence the commercial production of Sabin vaccine as from April 1961 which meant that it would be available for use in the autumn of 1961 ... I got in touch with the Surgeon General immediately for further information and am awaiting his reply. ${ }^{67}$

In the meantime, the UK continued using the inactivated vaccine in 1961. By the end of that year 16.7 million people had received two shots, and 12 million had had three. ${ }^{68}$ Sabin vaccine should be used only in case of epidemics, the Ministry of Health advised all LHAs in April 1961. ${ }^{69}$

When such an emergency occurred soon afterwards, attitudes changed dramatically. In September 1961 a serious outbreak of polio occurred in Hull. Very quickly the number of infected people in the hospitals rose. As the inactivated vaccine was not able to halt the epidemic, the Hull Health Authority asked the Ministry of Health's permission to use OPV. The Ministry agreed immediately, as it had the necessary supplies for such emergencies. Within a few days in mid-October, 385,000 people were vaccinated in Hull and the surrounding towns. By the end of the month the epidemic was under control. After this success, the Sabin vaccine became widely accepted in the UK. Even harsh critics of the live vaccine, such as George Dick, were now convinced. ${ }^{70}$ At the same time, the Joint

\footnotetext{
${ }^{65}$ NA, PRO, MH 133/468, Joint Committee on Poliomyelitis Vaccine, 14 Oct. 1959.

${ }^{66}$ Fifth International Poliomyelitis Conference, July 26-28, 1960, Copenhagen. Abstracts of papers presented, Amsterdam, 1960.

${ }^{67}$ NA, PRO, MH 55/2469, 'On live poliomyelitis vaccine', note by J A Charles, Sept. 1960.
}

\footnotetext{
${ }^{68}$ NA, PRO, MH 55/2469, Draft on Polio Vaccine, 9 May 1960 .

${ }^{69}$ NA, PRO, MH 55/2469, Polio Vaccination Programme, 15 Aug. 1960.

${ }^{70}$ NA, PRO, MH 55/2473, Ministry of Health to Commonwealth Department of Health, Australia, 25 Oct. 1961; Gould, op. cit., note 36 above, pp. 175-6.
} 


\section{Polio Vaccine Innovation and Adoption}

Committee on Poliomyelitis Vaccine developed guidelines for the further use of OPV: Sabin vaccine should be used for primary immunizations, courses of immunization which had started with inactivated vaccine should be concluded with IPV. On 24 October 1961 the Minister of Health announced the general introduction of oral vaccination with Sabin vaccine as an alternative form of polio vaccination. ${ }^{71}$

The Ministry prepared for the large-scale introduction of Sabin vaccine in early 1962, though not in the form of a blanket operation, i.e. a vaccination of the whole population, as had been done in very successfully in the Czech Republic and in West Germany. ${ }^{72}$ Socially and politically the ground was prepared. In Parliament the Minister of Health made an announcement about OPV on 31 January 1962. The medical journals had been informed beforehand, and the Royal Society for the Promotion of Health invited Albert Sabin to give a speech on the same day. A circular was sent to all Local Health Authorities about the new vaccine. A press release sent to the main newspapers compared the introduction of the live vaccine with the introduction of the smallpox vaccination and explained the reasons for the change of vaccine. ${ }^{73}$

Following the launch of this public campaign, OPV was used everywhere in the UK for primary immunization of children and teenagers. In April 1962 the Ministry of Health ruled that people who had already had a first shot of Salk vaccine could complete their immunization with Sabin vaccine. ${ }^{74}$ With this measure the changeover to Sabin vaccine was complete.

\section{Conclusions}

In summary, the facts we have presented are as follows. In the Netherlands IPV was introduced quickly and successfully, and no change to OPV took place later. In Britain the fairly successful introduction of IPV was delayed for two years, whilst there then followed a gradual, relatively slow change to use of OPV. In West Germany IPV vaccination was introduced very late and with very poor results. Here the change to OPV took place early and mass vaccination with this vaccine followed rapidly. As in Bryder's account of BCG introduction, the three countries show three completely different processes of vaccine introduction and use.

The first question, then, is why did the introduction of IPV proceed so differently in Germany, the Netherlands and the UK? All three countries were faced with serious annual polio epidemics. The number of cases per 100,000 population in 1955, when IPV became available, were 5.4, 4.5 and 14.1 (in England and Wales) respectively. Differences in national responses cannot be sought here.

Hollingsworth and his colleagues explore the consequences of different patterns of health service organization and finance (among other variables). ${ }^{75}$ Their hypothesis is

\footnotetext{
${ }^{71}$ NA, PRO, MH 55/2473, Poliomyelitis, Use of Live Oral Vaccine, 12 Oct. 1961; Report of the Chief Medical Officer on the state of public health, 1961, PP 1962-63, XIX, p. 47.

${ }^{72}$ NA, PRO, MH 133/474, Joint Committee on Poliomyelitis Vaccine, Minutes of Meeting, 23 Nov. 1962.
}

\footnotetext{
${ }^{73}$ NA, PRO, MH 55/2473, Sabin Polio Vaccine, 24 Jan. 1962.

${ }^{74}$ NA, PRO, MH 55/2473, Circular, 26 April 1962; NA, PRO, MH 55/2474, CMO to GPs, Routine Immunisation against Infectious Diseases, 9 March 1962.

${ }^{75}$ Hollingsworth, Hage and Hanneman, op. cit., note 11 above, pp. 112-37.
} 


\section{Ulrike Lindner and Stuart S Blume}

that a high degree of state centralization in a health system should lead to relatively slow adoption followed by rapid diffusion. Comparing the speed with which smallpox vaccination spread in Britain, France, Sweden and the US, in the late nineteenth and early twentieth centuries, they find support for their hypothesis. In the case of polio, vaccination with IPV would be expected to spread far more rapidly in the Netherlands and in the UK than in Germany. The Netherlands introduced a nationally planned and co-ordinated vaccination programme in 1957, precisely in order to ensure consistency and efficiency, whilst in Britain a centrally planned and administered National Health Service was already in place. Germany, by contrast, had a statutory health insurance scheme but a weak and fragmented public health system. Comparing the Netherlands with Germany, the hypothesis is borne out. But it fails to explain why diffusion of IPV in Britain was not as rapid as in the Netherlands despite the centralized NHS. Additional explanatory factors have to be sought.

The adequacy and responsiveness of vaccine supply to the needs of vaccination programmes could be one such factor. Innovation theorists have frequently stressed the importance of producer-user relations to successful innovation. ${ }^{76}$ Each country looked to national producers: commercial producers in Germany and the UK, a state producer in the Netherlands. As we saw, British and German suppliers had difficulties in producing rapidly vaccine of an adequate quality and in the necessary quantities. This was not the case in the Netherlands: admittedly a smaller country. The Dutch state institute, closely linked to the national vaccination programme, and with responsibility for meeting the programme's needs, was far more successful in producing the vaccine required than the private companies in the UK and in West Germany.

In addition to differences in the structural features of health systems and in the relations between vaccine production and public health systems, national attitudes to vaccination and to the vaccine also played a part. In Germany the mistrustful attitudes of health administrators and the scepticism of leading scientists clearly contributed to the hesitant response to IPV. Despite strong connections with US research institutions and early enthusiasm about the Salk vaccine, British health administrators were wary of US vaccine after the Cutter incident and thereafter acted cautiously.

When we consider responses to OPV after 1960, Hollingsworth's model proves still less adequate. The degree of centralized control over health services cannot explain the nondiffusion of OPV in the Netherlands, gradual diffusion in the UK, and rapid diffusion in West Germany.

The concept of path dependencies, borrowed from Rothman (and related, as noted above, to similar concepts used by innovation theorists) is more helpful in making sense of these differences. In the Netherlands strong national path dependencies had been created. The state institute (RIV) had developed a combination vaccine (incorporating IPV) and a vaccine production process specifically tailored to the country's vaccination requirements. Marketing possibilities outside the country's borders played no role. On the one hand the RIV was an influential insider in vaccine policy making; on the other, the Dutch Ministry of Health was in a position to orchestrate not only vaccination, but vaccine

\footnotetext{
${ }^{76} \mathrm{R}$ R Nelson and S G Winter, 'In search of a useful theory of innovation', Research Policy, 1977, 6: 36-76.
} 


\section{Polio Vaccine Innovation and Adoption}

development and production as well. The programme had been highly effective, both in terms of coverage and in terms of disease incidence. With an effective programme of IPV vaccination, the Netherlands had rapidly brought polio under control. Thus in 1960 not only did morbidity statistics provide no important incentive to change, but investments made in IPV production, and the link between production and use, can all be seen as having provided disincentives to change over to OPV. The fact that other countries were switching en masse to OPV carried little weight in Dutch deliberations.

In Germany in 1960 matters were quite different. IPV had reached only a very small percentage of the population and there were still more than 4,000 cases of acute polio per annum. The country's failure to bring polio under control was a source of growing concern, though not in the sense that the statistics "spoke for themselves". A major impetus to change derived from the international environment of the Cold War era. Significant for West German policy makers was the competition with the GDR, and they paid careful attention to what had been accomplished there. The logic of our argument implies that strong institutional commitments could have led policymakers to place the most favourable gloss possible on available statistics, thus down-playing the failure of existing programmes. However this was not the case. No strong path dependencies of this kind had been created. Links between vaccination programmes and vaccine production were far weaker in Germany than in the Netherlands. The manufacturer, Behringwerke, was not tied to the health authorities in the way that the RIV was. It may be surmised that even if the company did try to protect its investments in IPV technology, it would have been less influential than the RIV in the Netherlands.

Turning finally to the UK, we find a situation midway between those of Germany and the Netherlands. Only after delays and struggles did the British IPV vaccination programme reach the necessary percentage of the population, morbidity rates declining from 1959 onwards. But an initial commitment to IPV did not give rise to the same path dependency as in the Netherlands for reasons similar to those given earlier. Commitment to IPV was shaken by the effective deployment of OPV in fighting the alarming Hull epidemic in 1961. The commercial manufacturer was not following the vaccination programme but was making its own decisions on a commercial basis. Glaxo started to produce OPV even before the British had decided to introduce it. And finally, the international environment played a part. There was a strong connection to the US scientific community and health administration. When the US changed to OPV the British were inclined to follow.

This comparative analysis of vaccine innovation and adoption leads to conclusions that overlap with, but extend, the findings of Stanton and of Bryder. First, in common with those authors - and in sharp contrast with much contemporary health policy analysis - we conclude that scientific and epidemiological data did not "determine" the introduction of the polio vaccines. Differences in the introduction of IPV far outweighed differences in the burden of disease in each of the three countries. Epidemiological data, and studies of the (relative) merits of the two vaccines, lent themselves to differing interpretations. They could be, and were, read in different ways. Structural features of health systems, central both to Stanton's analysis and to Hollingsworth's model, also played an important, though not determining, role in explaining national differences. Moreover, and in line with much current innovation theory, we suggest that different responses to the emergence of the polio vaccines have to be understood also in terms of differences in linkage between national 


\section{Ulrike Lindner and Stuart S Blume}

systems of vaccine production and of public health. ${ }^{77}$ How directly are the needs of vaccination programmes translated into priorities for vaccine manufacturers? The concept of a national system of innovation, as a broad conceptual framework allowing for the inclusion of institutional, organizational, social and political factors as well as economic ones, seems potentially useful as a means of capturing this. ${ }^{78}$

Bryder's analysis stresses the importance of established traditions and professional commitments in shaping responses to the emergence of BCG. We found something similar here. Where existing ways of combating polio could plausibly be viewed as successful, there was little incentive to change: developments could be subsumed under the notion of path dependency as we suggested earlier. But here too the epidemiological evidence could be interpreted in different ways, and is not in itself sufficient to explain action or inaction. How data were interpreted depended on general attitudes of national scientific communities and the public, and on institutional commitments. The extent of institutional commitment to IPV in both production and use ${ }^{79}$ was a crucial source of this path dependency. In addition to all this, and not noted by previous authors, our analysis has suggested the varied and changing influence of international relations, shaped in this case by the Cold War. A question for further research, and one highly relevant to the broader question of historically changing dynamics of vaccine innovation, is that of how international standards and pressures were experienced at the national level, and how this varies between countries. $^{80}$

Over the past few years, insights from the field of innovation studies have proved fruitful for medical history, and medical historical research has enriched understanding of innovation processes. ${ }^{81}$ Unlike most other innovation studies, when looking at medical innovations and their diffusion in different countries, as we do in this paper, the context- the specific health system with its historically changing organization, culture, and cost constraints - has to be taken into account. ${ }^{82} \mathrm{We}$ are convinced that comparative historical analysis such as we have attempted here can enrich not only the field of innovation studies, but substantive policy debates such as now take place in the vaccine field.

\footnotetext{
${ }^{77} \mathrm{C}$ Edquist, 'Innovation policy - a systemic approach', in D Archibugi and B- $\AA$ Lundvall (eds), The globalizing learning economy, Oxford University Press, 2001, pp. 219-38.

${ }^{78} \mathrm{C}$ Edquist, 'Systems of innovation approaches their emergence and characteristic', in idem (ed.), Systems of innovation: technologies, institutions and organizations, London and Washington, Pinter, 1997, p. 17; R Nelson and K Nelson, 'Technology, institutions and innovation systems', Research Policy, 2002, 31: 265-72, and their broad definition of institutions as "widely employed social technologies" in their understanding of systems of innovation.

${ }^{79}$ Or more generally what David calls "lock in" and Thomas Hughes "technological momentum". See David, op. cit., note 15 above, and T P Hughes, 'The evolution of large technological systems', in W E Bijker, T P Hughes and T J Pinch (eds), The social construction of technological systems, Cambridge, MA, MIT Press, 1987, pp. 51-82.
}

\footnotetext{
${ }^{80}$ We can distinguish effects due to international standards, economic pressures (reflecting, for example, growing concentration in the vaccines industry), and political pressures (e.g., the rivalry between countries, the growing importance of global forums in seeking to structure global vaccination efforts and vaccine development).

${ }^{81}$ For example, J V Pickstone (ed.), Medical innovations in historical perspective, Basingstoke, Macmillan, 1992; J P Gaudillière and I Löwy (eds), The invisible industrialist: manufacture and the construction of scientific knowledge, Basingstoke, Macmillan, 1998; J Stanton (ed.), Innovations in health and medicine: diffusion and resistance in the twentieth century, London, Routledge, 2002.

${ }^{82} \mathrm{~J}$ Stanton, 'Introduction. On theory and practice', in idem (ed.), Innovations in health and medicine. Diffusion and resistance in the twentieth century, London, Routledge, 2002, pp. 2-4.
} 